\title{
The Spiritual Well-Being Scale (SWBS) in Greek Population of Attica
}

\author{
Panagiota Darvyri1", Michael Galanakis², Adamantios G. Avgoustidis ${ }^{3}$, Spyros Vasdekis ${ }^{4}$, \\ Artemios Artemiadis $^{1}$, Xanthi Tigani ${ }^{1}$, George P. Chrousos ${ }^{1,5^{*}}$, Christina Darviri ${ }^{{ }^{*}}$ \\ ${ }^{1}$ Postgraduate Course Stress Management and Health Promotion, School of Medicine, University of Athens, \\ Athens, Greece \\ ${ }^{2}$ Panteion University of Social and Political Sciences, Athens, Greece \\ ${ }^{3}$ Pastoral Theology and Psychology, Theological School, National and Kapodistrian University of Athens, Athens, \\ Greece \\ ${ }^{4}$ Athens University Vascular Unit, University Hospital "Attikon", Athens, Greece \\ ${ }^{5}$ First Department of Pediatrics, Children's Hospital Aghia Sofia, School of Medicine, University of Athens, \\ Athens, Greece \\ Email:"pandarviri@yahoo.gr
}

Received 24 June 2014; revised 21 July 2014; accepted 15 August 2014

Copyright (C) 2014 by authors and Scientific Research Publishing Inc.

This work is licensed under the Creative Commons Attribution International License (CC BY).

http://creativecommons.org/licenses/by/4.0/

(c) $\underset{\mathrm{EY}}{\mathrm{BY}}$ Open Access

\section{Abstract}

The purpose of this study was to standardize a Greek version of the Spiritual Well-Being Scale and to study its psychometric qualities on Greek population. The questionnaire was completed by 496 adults from several areas of Attica $(31.9 \%=$ male adults), while the sample's average age was 31.33 years old. Age ranged from 18 to 69 years old. Based on the eigenvalues produced by the factor analysis, a three factors solution ("Affiliation with God", "Satisfaction with life" and "Alienation from God-sense of meaningless life") was used. These three factors account for $51.492 \%$ of the variance. Nevertheless the three factors found in the Greek standardization differ from those of the original standardization, providing reason to believe that spiritual well-being among Greeks is different than well-being among US College Students. According to the final structure, the 1st factor's reliability was $\alpha=0.882$, the 2nd factor's $\alpha=0.738$ and the 3rd factor's $\alpha=0.669$. The results of the analysis demonstrate that the final form of the Scale can be safely used on similar studies concerning Greek population. Applications and value of the results are included in the discussion.

\section{Keywords}

Spiritual Well-Being, Religiousness, Standardization

*These authors contributed equally and share last authorship.

"Corresponding author.

How to cite this paper: Darvyri, P. et al. (2014). The Spiritual Well-Being Scale (SWBS) in Greek Population of Attica. Psychology, 5, 1575-1582. http://dx.doi.org/10.4236/psych.2014.513168 


\section{Introduction}

Until today, there is no universally accepted scientific definition of spirituality and no consensus concerning its significance on research and health (Cobb \& Robshaw, 1998; Moberg, 2002). Several efforts resulted in numerous distinct meanings of spirituality (Moberg, 2002). The definitions of spirituality often include a sense of transcendence as well as other dimensions, including purpose or meaning of life, reliance on internal resources, sense of self-fulfilment or cohesion and (Chandler, Holden, \& Kolander, 1992; Miller \& Thoresen, 2003; Moberg, 2002; Monod et al., 2011) district beliefs and values. Therefore, spirituality can have different meanings to different people (Egan, 2010). Spiritual well-being (SWB) can be an indispensable companion to the concept of spirituality; it is closely connected with it (Imam, Abdul Karim, Jusoh \& Mamad, 2009). Similarly, SWB is not synonymous to the mental and physical health, but it is likely to be associated with these two variables (Paloutzian, Bufford, \& Wildman, 2012).

Psycho-spiritual well-being is an area of interest to researchers all over the world. Spiritual well-being is described as a dual status which includes: 1) a vertical dimension referring to well-being in relation to God or a higher power; i.e. referring to the religious element, and 2) a horizontal dimension referring to the purpose and satisfaction from life; i.e. referring to a spiritual or existential component (Monod et al., 2011; Cooper-Effa, Blount, Kaslow, Rothenberg, \& Eckman, 2001; Ellison, 1983).

Individuals with high and low spiritual well-being portrayed substantially different personality profiles. According to the results of studies, the high spiritual well-being group scored lower on neuroticism and higher on extraversion, agreeableness and conscientiousness than the low spiritual well-being group. Paloutzian and Ellison reported that spiritual well-being is positively related with the purpose of life, intrinsic religious commitment and self-esteem, while negatively related to individualism, individual freedom and loneliness. These results show that individuals with high spiritual well-being tend to portray more positive personalities in comparison with low spiritual well-being individuals (Ramanaiah, 2001).

A systematic review in 2011 identified 35 instruments used in clinical trials to assess multiple dimensions of spirituality and to measure its association with impact on health. The most popular and widely used scale is SWBS (Koenig \& Cohen, 2002), designed by Paloutzian and Ellison in 1982. This scale is intended to assess the individuals' subjective perception of their quality of life in relation with spirituality, as perceived through religious and existential dimensions (Moberg \& Brusek, 1978; Moberg, 1979) and it is utilized in studies concerning clinical and general health cases (Koenig \& Cohen, 2002). Since it is non-sectarian it can be used in a variety of religious and cultural backgrounds, in health, and in general research (Imam, Abdul Karim, Jusoh, \& Mamad, 2009; Musa \& Pevalin, 2012). SWBS has been translated and validated into several languages, including Spanish, Arabic, Malay, (Imam, Abdul Karim, Jusoh, \& Mamad, 2009; Koening \& Cohen, 2002; Musa \& Pevalin, 2012) Portuguese and Chinese (Paloutzian, Bufford, \& Wildman, 2012).

The notion of spiritual well-being is different to the idea of health or maturity in terms of spirituality, or to the notion of spirituality itself. It has been designed on two main components: one religious and one social-psychological component. From those two components, two subscales emerge which compose the Scale: 1) Religious Well-being subscale (RWB), and 2) Existential Well-being subscale (EWB) (Moberg \& Brusek, 1978; Moberg, 1971). Religious Well-being subscale (RWB) focuses on how well individuals feel in regards with and in relation with God. To that end, all questions included in RWB Scale contain the word "God”. Existential Well-being subscale (EWB) focuses on the ability of the individuals to adjust to themselves, their life, living, social environment and community (Boivin, Kirby, Underwood, \& Silva, 1999). The questions included in this subscale do not refer to specific religious issues. They refer to general issues concerning the meaning of and satisfaction with life (Koenig \& Cohen, 2002; Bruce, 1997).

SWBS is easy to understand and includes clear scoring guidelines (Imam, Abdul Karim, Jusoh, \& Mamad, 2009), portrays good conceptual validity, as well as ostensible validity, proven by the questions' content (Bufford, Paloutzian, \& Ellison, 1991; Paloutzian \& Ellison, 1982). Its construct validity has been supported by factor analysis (Ellison, 1983; Phillips, Mock, Bopp, Dudgeon, \& Hand, 2006). Its overall reliability is extensively endorsed by existing bibliography, with Cronbach’s alpha exceeding 0.82 (Phillips, Mock, Bopp, Dudgeon, \& Hand, 2006). Cronbach's alpha for RWBS ranges between 0.82 and 0.99 and for EWBS from 0.73 to 0.98 (Brinkman, 1989; Phillips, Mock, Bopp, Dudgeon, \& Hand, 2006).

Scales SWB, RWB, and EWB are positively correlated with positive self-perception, sense of purpose and meaning of life, self-confidence, physical health, emotional adjustment, locus of control, as well as higher self- 
confidence and less aggressiveness. They are negatively correlated with distress, poor health, low ability for emotional adjustment, dissatisfaction with life and lack of purpose in life (Brinkman, 1989; Bufford, Paloutzian, \& Ellison, 1991; Phillips, Mock, Bopp, Dudgeon, \& Hand, 2006).

This paper studies the adaptation of Spiritual Well-being Scale (SWBS) to the Greek population and, more specifically, to health professionals working at hospitals and to students from various faculties of Universities and Technological Educational Institutes. Since SWBS has not been standardized in Greece, our goal is to study the scale's psychometric qualities on our sample. The purpose of our research is 1) to translate into Greek and 2) to standardize SWBS on Greek population. Since the notion of Spiritual well-being is negatively related to distress and positively related to locus of control we used measures of the above variables as convergent and divergent validity indexes for the Greek Version of SWBS.

\section{Method}

\subsection{Participants}

496 adults from various areas of Attica participated in this research. Men's percentage was $31.9 \%(\mathrm{~N}=158)$ and women's percentage $67.5 \%(\mathrm{~N}=335)$, while the sample's average age was 31.33 years old, ranging from 18 to 69 with a standard deviation of $9.9(\mathrm{SD}=9.9) .3$ participants did not state their sex, hence the percentages sum up to less than $100 \%$.

\subsection{Tools}

Demographic Data: In order to complete this study, we created a demographic data-series of items. This series of items includes information concerning gender, age, marital status, educational level and profession.

The Spiritual Well-being Scale: It has been designed on two main components: one religious and one socialpsychological component. From those two components, two subscales derive which compose the Scale: 1) Religious Well-being subscale (RWB), and 2) Existential Well-being subscale (EWB) (Moberg, 1971; Moberg \& Brusek, 1978; Paloutzian \& Ellison, 1982; Moberg, 1984). It is a self-report instrument and it takes 10 - 15 minutes to complete. This psychometric instrument contains 20 questions and each one of them is answered on a 6point Likert-type scale ( 1 = strongly agree, 6 = strongly disagree). Approximately half of the questions are negatively worded, in order to limit possible biased responses (Bufford, Paloutzian, \& Ellison, 1991; Ellison \& Paloutzian, 1991/2009).

Health Locus of Control Scale: We utilized the Health Locus of Control (HLoC) 18-item questionnaire, by Waltson, B.S. and Waltson, K.A. Individuals are invited to rate 18 statements according to the degree of their agreement on a Likert scale ( $1=$ Strongly disagree to $6=$ Strongly agree). There are three 6 -item subscales: The first subscale (HLC1) measures the degree to which the individual feels in control of his/her health. The second subscale (HLC2) measures the degree to which the individual believes that others control his/her health, and the third one (HLC3) measures the degree to which the individual believes that his/her health is a matter of chance. The questionnaire is adapted in Greek with adequate internal consistency (Cronbach's alpha = 0.72) (Stalikas, Triliva, \& Roussi, 2002).

Perceived Stress Scale: Stress was measured on the basis of the 14-item Perceived Stress Scale (PSS) by Cohen S. (Cohen, Kamarck, \& Mermelstein, 1983). The individual is invited to answer 7 positively stated and 7 negatively stated questions concerning his/her emotions and thoughts over the last month on a Likert-type scale ( 1 = Never to 5 = Very often). Overall score is obtained by summing all the answers' scores, having previously reversed the responses of positive questions. High score indicates higher level of perceived stress. The questionnaire has been standardized in Greek with adequate internal consistency (Cronbach’s alpha $=0.79$ ) (Andreou et al., 2011).

\subsection{Procedure}

Translation: Translation was carried out using forward/backward translation method (1997) by two translators. The Greek version was pre-tested on a small sample (approximately five individuals) in order to trace unclear parts of the questions and to determine the final assessment of the translation.

Spiritual Well-being Scale's license: As all rights of the Scale are reserved by its authors (Ellison \& Paloutzian, 1991/2009), we acted accordingly. 
Data Collection: We distributed the questionnaires between January 2012 and May 2013. We thoroughly informed the participants of the purpose of the research and they voluntarily offered to complete the questionnaires.

Data was collected in an anonymous and confidential manner. During the questionnaires' completion no questions arose due to lack of clarity. All participants were advised to leave blank any questions which they did not wish to answer. The average completion time was 30 minutes. The return rate of the distributed questionnaires was $90 \%$.

\section{Results}

The analysis was performed on 496 individuals. Based on the correlation matrix, correlations range from 0.004 (SWBS1 with SWBS8) to 0.683 (SWBS17 with SWBS19). Determinant was $0.001 \geq 0.00001$ indicating absence of undesirable very high correlation of variables. Barlett's test of Sphericity turned out statistically significant $\left(\chi^{2}\right.$ $p<0.001)$ ), indicating satisfactory correlation level among variables. Kaiser-Meyer-Olkin test value is 0.874 $(>0.5)$, thus confirming sampling adequacy. Furthermore, KMO value for each variable was $>0.5$, indicating that the sample was adequate for each variable individually.

The eigenvalues of three factors were $\geq 1$ and in combination accounted for $51.49 \%$ of variance. Scree plot (Figure 1) indicated that three factors should be retained. The option of three factors prevailed due to enhanced factor interpretation. Table 1 includes the final results of the factor analysis.

The items of factor 1 concern the person's belief that God takes care of him/her and he/she is experiencing a positive relationship with God. We labelled this factor "Affiliation with God". Items of factor 2 concern the person's general feeling of satisfaction with life and his/her sense of meaning of life, therefore we labelled this factor "Satisfaction with life". Items of factor 3 concern the person's sense of distance from God and his/her disappointment from life, therefore factor 3 was labelled "Alienation from God-sense of meaningless life".

Table 2 presents the subscales' basic descriptive measures (questions 1 and 5 have been reversed).

The subscales' correlation is presented in Table 3. According to this table, higher sense of satisfaction with life is connected to stronger relationship with God. On the contrary, alienation from God is significantly connected with lower sense of satisfaction with life and weaker relationship with God.

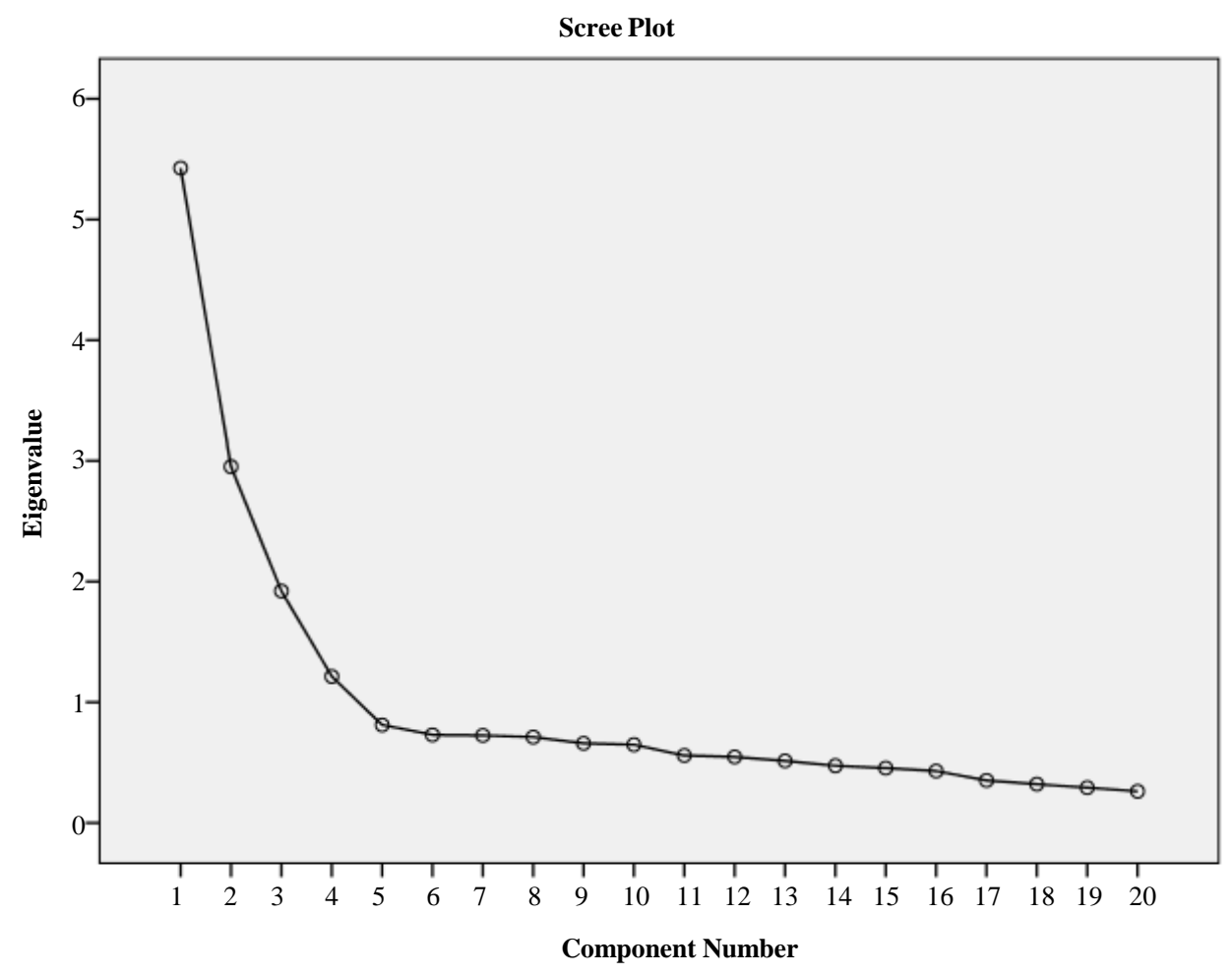

Figure 1. The scree plot of the factors' eigenvalues concerning the SWB Scale. 
Table 1. Results of principal component analysis after orthogonal rotation of factors pertaining to SWB Scale.

\begin{tabular}{|c|c|c|c|c|}
\hline Number & Questions & $\begin{array}{l}\text { Affiliation } \\
\text { with God }\end{array}$ & $\begin{array}{l}\text { Satisfaction } \\
\text { with life }\end{array}$ & $\begin{array}{l}\text { Alienation from God-sense } \\
\text { of meaningless life }\end{array}$ \\
\hline SWS1 & I don't find much satisfaction in private prayer with God. & -0.566 & 0.142 & 0.472 \\
\hline SWS3 & I believe that God loves me and cares about me. & 0.763 & 0.168 & -0.125 \\
\hline SWS5 & $\begin{array}{l}\text { I believe that God is impersonal and not interested in my daily } \\
\text { situations. }\end{array}$ & -0.531 & 0.097 & 0.446 \\
\hline SWS7 & I have a personally meaningful relationship with God. & 0.738 & 0.216 & -0.079 \\
\hline SWS11 & I believe that God is concerned about my problems. & 0.733 & 0.147 & -0.086 \\
\hline SWS15 & My relationship with God helps me not to feel lonely. & 0.775 & 0.110 & 0.007 \\
\hline SWS17 & I feel most fulfilled when I'm in close communion with God. & 0.804 & 0.091 & 0.087 \\
\hline SWS19 & My relation with God contributes to my sense of well-being. & 0.825 & 0.121 & 0.050 \\
\hline SWS4 & I feel that life is a positive experience. & 0.119 & 0.630 & -0.78 \\
\hline SWS8 & I feel very fulfilled and satisfied with life. & 0.043 & 0.775 & -0.081 \\
\hline SWS10 & $\begin{array}{l}\text { I feel a sense of well-being about the direction my life is } \\
\text { headed in. }\end{array}$ & 0.154 & 0.757 & -0.055 \\
\hline SWS14 & I feel good about my future. & 0.095 & 0.607 & -0.192 \\
\hline SWS20 & I believe there is some real purpose for my life. & 0.369 & 0.559 & -0.041 \\
\hline SWS2 & $\begin{array}{l}\text { I don't know who I am, where I came from, or where I'm } \\
\text { going. }\end{array}$ & -0.109 & -0.081 & 0.632 \\
\hline SWS6 & I feel unsettled about my future. & -0.027 & -0.143 & 0.450 \\
\hline SWS9 & I don’t get much personal strength and support from my God. & -0.381 & 0.184 & 0.492 \\
\hline SWS12 & I don't enjoy much about life & 0.222 & -0.469 & 0.573 \\
\hline SWS13 & I don’t have a personally satisfying relationship with God. & -0.343 & 0.029 & 0.618 \\
\hline SWS16 & I feel that life is full of conflict and unhappiness. & 0.242 & -0.268 & 0.472 \\
\hline SWS18 & Life doesn't have much meaning. & 0.140 & -0.337 & 0.586 \\
\hline Eigen values & & 4.784 & 2.883 & 2.642 \\
\hline$\%$ of variance & & 23.911 & 14.4 & 13.181 \\
\hline Cronbach's a & & 0.882 & 0.738 & 0.669 \\
\hline
\end{tabular}

Analysis information: Determinant $=0.01$, Barlett's test: $\chi^{2}(p<0.001), p=0.00$, Kaiser-Myer-Olkin $=0.874$, residuals of $\geq 0.05=39 \%$, mean communality $=0.52$

Table 2. Descriptive measures of SWB Scale’s three subscales.

\begin{tabular}{cccccc} 
Factor & Number of items & Mean & SD & Min & Max \\
Affiliation with God & 8 & 25.17 & 8.39 & 48 \\
Satisfaction with life & 5 & 13 & 4.11 & 5 \\
Alienation from God-sense of meaningless life & 7 & 28.77 & 5.31 & 12 \\
\hline
\end{tabular}

Table 3. Correlation of SWB scale's factors.

\begin{tabular}{|c|c|c|c|}
\hline & Affiliation with God & Satisfaction with life & $\begin{array}{c}\text { Alienation from God-sense of } \\
\text { meaningless life }\end{array}$ \\
\hline Affiliation with God & 1 & & \\
\hline Satisfaction with life & $0.314^{*}$ & 1 & \\
\hline $\begin{array}{c}\text { Alienation from God-sense of } \\
\text { meaningless life }\end{array}$ & $-0.259^{*}$ & $-0.376^{*}$ & 1 \\
\hline
\end{tabular}

${ }^{*} p<0.05$ (two-tailed). 
Individuals with better "Affiliation with God” portrayed higher internal health locus of control (Pearson's $\mathrm{r}=$ $-0.133, p=0.04$ ) and lower external health locus of control ("Powerful others") (Pearson's $r=-0.132, p=0.05$ ). Individuals with lower "satisfaction with life" were more stressed (Pearson's $r=0.299, p \leq 0.001$ ), had lower internal health locus of control (Pearson's $r=-0.167, p \leq 0.001$ ) and higher health locus of control attributed to external factors, such as chance (Pearson's $r=0.184, p \leq 0.001$ ). Individuals with lower "Alienation from Godsense of meaningless life" experienced higher levels of satisfaction in various domains of their life (Pearson's $r=$ $0.384, p \leq 0.001$ ), less stress (Pearson's $r=0.380, p \leq 0.001$ ), higher internal health locus of control (Pearson's $r=$ $0.119, p \leq 0.01$ ), and lower health locus of control attributed to external factors, such as chance (Pearson's $r=$ $-0.236, p \leq 0.001)$.

\section{Discussion}

In recent years, special emphasis is attributed to the relation between spirituality and spiritual, psychological and physical health, highlighting the important impact that spiritual well-being has on health (Anandarajah \& High, 2001; Huitt \& Robbins, 2003). In particular, spiritual well-being is positively connected to purpose of life, social support, lower stress levels and lower depression rates (Yi et al., 2006).

The present study provides preliminary support for the reliability and validity of a Greek version of the SWBS. Adaptation was based on data collected from 496 individuals residing in urban areas, using common component analysis. Three-component structure is supported by previous studies (Musa \& Pevalin, 2012) and in our study it accounts for $51.49 \%$ of the tool's variance. The questions' loadings onto the factors were satisfactory, including two negative loadings which had to be reversed during score calculation. The internal reliability of the three factors was also satisfactory, as shown in other studies (Boivin, Kirby, Underwood, \& Silva, 1999; Bufford, Paloutzian, \& Ellison, 1991). Finally, it should be noted that the Scale's two dimensions have not been clearly confirmed and some studies indicate that its factorial structure might be more complex than expected (Genia \& Shaw, 1991). In our sample, factor labelled "Alienation from God-sense of meaningless life" included questions usually listed in both existential and spiritual well-being, with a distinctive negative wording, confirmed by the positive loadings in the analysis table. This result could be justified by social-cultural factors, e.g. strong connection between existential approach and religious causality. The absence of this type of matching in the questions of factors "Affiliation with God" and "Satisfaction with life"-which could potentially match the factors of "Religious well-being" and "Existential well-being" respectively—is probably related to the positive nature of the questions. In particular, we assume that the above-mentioned matching of religious and existential approaches works in negative responses, at least among Greek population. The three factors found in the Greek standardization differ from those of the original standardization, providing reason to believe that spiritual wellbeing among Greeks is different than well-being among US College Students.

As previous studies have presented, social-demographic data do not correlate significantly with the subscales' scores (Büssing, Balzat, \& Heusser, 2010). In our analysis we also traced useful correlations associated indirectly with health, such as perceived stress and health locus of control. Results point out that individuals with better relationship with God and higher satisfaction with life experienced less stress and stronger internal health locus of control, as expected. These findings possibly indicate the protective impact of high spiritual well-being on better health, as mentioned in this study's introduction (Hodge, 2003; Anandarajah \& High, 2001; Koenig, 2002; Bredle, Salsman, Debb, Arnold, \& Cella, 2011; Cotton, Levine, Fitzpatrick, Dold, \& Targ 1999).

The study has several limitations. It is not safe to generalize the results to the whole of the Greek population, as our sample comprises exclusively of citizens of Athens. Nevertheless, our large sample allows us to recommend this tool for future Greek studies. Another limitation is that no test-retest was performed. Future studies should include a test-retest. Finally, we should mention that there has been no prior study with comparable goals in Greece, which would allow safer control of the criterion validity.

\section{Conclusion}

In conclusion, the present version of SWBS demonstrates satisfactory psychometric properties (content validity, internal reliability) and it is recommended as a future tool in studies researching the Greek population's health. Although our research demonstrates satisfactory psychometric qualities, we believe that further weighting on special parts of the population (e.g. clerics) would add new elements related to the variable in Greece. We are certain that it should constitute a further step of future studies by contemporary researchers. 


\section{Conflict of Interest}

The authors have no conflict of interest to declare.

\section{References}

Anandarajah, G., \& High, E. (2001). Spirituality and Medical Practice: Using the HOPE Questions as a Practical Tool for Spiritual Assessment. American Family Physician, 63, 81-89.

Andreou, E., Alexopoulos, E. C., Lionis, C., Varvogli, L., Gnardellis, C., Chrousos, G. P., \& Darviri, C. (2011). Perceived Stress Scale: Reliability and Validity Study in Greece. International Journal of Environmental Research and Public Health, 8, 3287-3298. http://dx.doi.org/10.3390/ijerph8083287

Boivin, M. J., Kirby, A. L., Underwood. L. K., \& Silva, H. (1999). Review of the Spiritual Well-Being Scale. In P. C. Hill, \& R. W. Hood Jr. (Eds.), Measures of Religiosity (pp. 382-385). Birmingham, AL: Religious Education Press.

Bredle, J. M., Salsman, J. M., Debb, S. M., Arnold, B. J., \& Cella, D. (2011). Spiritual Well-Being as a Component of Health-Related Quality of Life: The Functional Assessment of Chronic Illness Therapy-Spiritual Well-Being Scale (FACIT-Sp). Religions, 2, 77-94. http://dx.doi.org/10.3390/ijerph8083287

Brinkman, D. D. (1989). An evaluation of the Spiritual Well-Being Scale: Reliability and Response Measurement. Dissertation, Abstracts, University Microfilms International, 50.

Bufford, R. K., Paloutzian, R. F., \& Ellison, C. W. (1991). Norms for the Spiritual Well-Being Scale. Journal of Psychology and Theology, 19, 56-70.

Büssing, A., Balzat, H. J., \& Heusser, P. (2010). Spiritual Needs of Patients with Chronic Pain Diseases and Cancer-Validation of the Spiritual Needs Questionnaire. European Journal of Medical Research, 15, 266-273. http://dx.doi.org/10.1186/2047-783X-15-6-266

Chandler, C. K., Holden, J. M., \& Kolander, C. A. (1992). Counseling for Spiritual Wellness: Theory and Practice. Journal of Counseling \& Development, 71, 168-175. http://dx.doi.org/10.1002/j.1556-6676.1992.tb02193.x

Cobb, M., \& Robshaw, V. (1998). The Spiritual Challenge of Health Care. Churchill Livingstone: Elsevier Health Sciences, 73-88.

Cohen, S., Kamarck, T., \& Mermelstein, R. (1983). A Global Measure of Perceived Stress. Journal of Health and Social Behavior, 24, 385-396. http://dx.doi.org/10.2307/2136404

Cooper-Effa, M., Blount, W., Kaslow, N., Rothenberg, R., \& Eckman, J. (2001). Role of Spirituality in Patients with Sickle Cell Disease. Journal of the American Board of Family Practice, 14, 116-122.

Cotton, S. P., Levine, E. G., Fitzpatrick, C. M., Dold, K. H., \& Targ, E. (1999). Exploring the Relationships among Spiritual Well-Being, Quality of Life and Psychological Adjustment in Women with Breast Cancer. Psycho-Oncology, 8, $429-438$. http://dx.doi.org/10.1002/(SICI)1099-1611(199909/10)8:5<429::AID-PON420>3.0.CO;2-P

Egan, R. (2010). Health Promotion and Spirituality: Making the Implicit Explicit. Keeping Up to Date, 34, 1-4.

Ellison, C. W. (1983). Spiritual Well-Being: Conceptualization and Measurement. Journal of Psychology \& Theology, 11, 330-340.

Huitt, W. G., \& Robbins, J. L. (2003). An Introduction to Spiritual Development. 11th Annual Conference: Applied Psychology in Education, Mental Health, and Business, Valdosta, GA, 3 October 2003. http://www.edpsycinteractive.org/papers/spirituality.pdf

Koenig, H. G. (2002). Spirituality in Patient Care: Why, How, When, and What. Radnor, PA: Templeton Foundation Press.

Koenig, H. G., \& Cohen, H. J. (2002). The Link between Religion and Health, Psychoneuroimmunology and the Faith Factor. Oxford: Oxford University Press. http://dx.doi.org/10.1093/acprof:oso/9780195143607.001.0001

Miller, W. R., \& Thoresen, C. E. (2003). Spirituality, Religion, and Health: An Emerging Research Field. American Psychologist, 58, 24-35. http://dx.doi.org/10.1037/0003-066X.58.1.24

Moberg, D. O. (1971). Spiritual Well-Being: Background. Washington DC: University Press of America.

Moberg, D. O. (1979). The Development of Social Indicators of Spiritual Well-Being for Quality of Life Research: Prospects and Problems. Sociological Analysis, 40, 11-26. http://dx.doi.org/10.2307/3710493

Moberg, D. O. (1984). Subjective Measures of Spiritual Well-Being. Review of Religious Research, 25, 351-364. http://dx.doi.org/10.2307/3511368

Moberg, D. O. (2002). Assessing and Measuring Spirituality: Confronting Dilemmas of Universal and Particular Evaluative Criteria. Journal of Adult Development, 9, 47-60. http://dx.doi.org/10.1023/A:1013877201375

Moberg, D. O., \& Brusek, P. M. (1978). Spiritual Well-Being: A Neglected Subject in Quality of Life Research. Social Indicators Research, 5, 303-323. http://dx.doi.org/10.1007/BF00352936 
Paloutzian, R. F., \& Ellison, C. W. (1982). Loneliness, Spiritual Well-Being and the Quality of Life. In L. A. Peplau, \& D. Perlman (Eds.), Loneliness: A Sourcebook of Current Theory, Research and Therapy (pp. 224-236). New York: John Wiley \& Sons.

Paloutzian, R. F., Bufford, R. K., \& Wildman, A. J. (2012). Spiritual Well-Being Scale: Mental and Physical Health Relationships. Section IV, Chapter 48, 353-358.

Phillips, K. D., Mock, K. S., Bopp, C. M., Dudgeon, W. A., \& Hand, G. A. (2006). Spiritual Well-Being, Sleep Disturbance and Mental and Physical Health Status in HIV-Infected Individuals. Issues in Mental Health Nursing, 27, 125-139. http://dx.doi.org/10.1080/01612840500436917

Stalikas, A., Triliva, S., \& Roussi, P. (2002). The Psychometric Tools in Greece. Athens: Greek Letters. (In Greek)

Yi, M. S., Mrus, J. M., Wade, T. J., Mona L. Ho., Hornung, R. W., Cotton, S., Peterman, A. H., Puchalski, C. M., \& Tsevat, J. (2006). Religion, Spirituality and Depressive Symptoms in Patients with HIV/AIDS. Journal of General Internal Medicine, 21, S21-S27. http://dx.doi.org/10.1111/j.1525-1497.2006.00643.x 
Scientific Research Publishing (SCIRP) is one of the largest Open Access journal publishers. It is currently publishing more than 200 open access, online, peer-reviewed journals covering a wide range of academic disciplines. SCIRP serves the worldwide academic communities and contributes to the progress and application of science with its publication.

Other selected journals from SCIRP are listed as below. Submit your manuscript to us via either submit@scirp.org or Online Submission Portal.
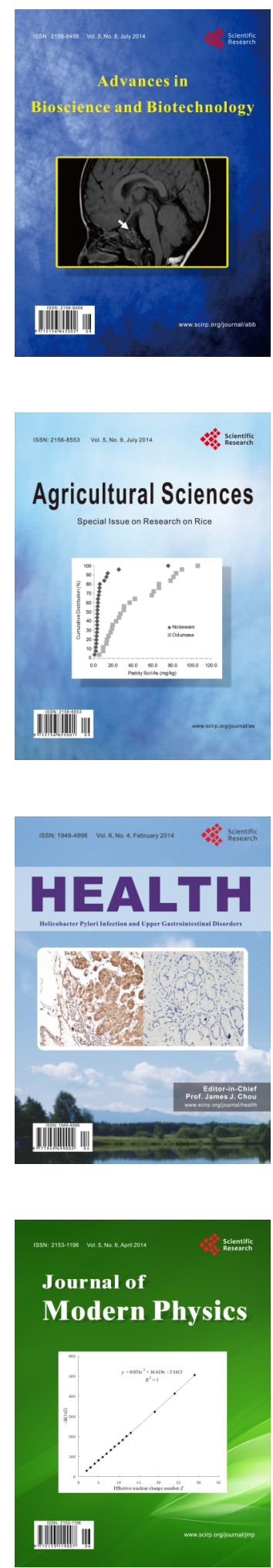
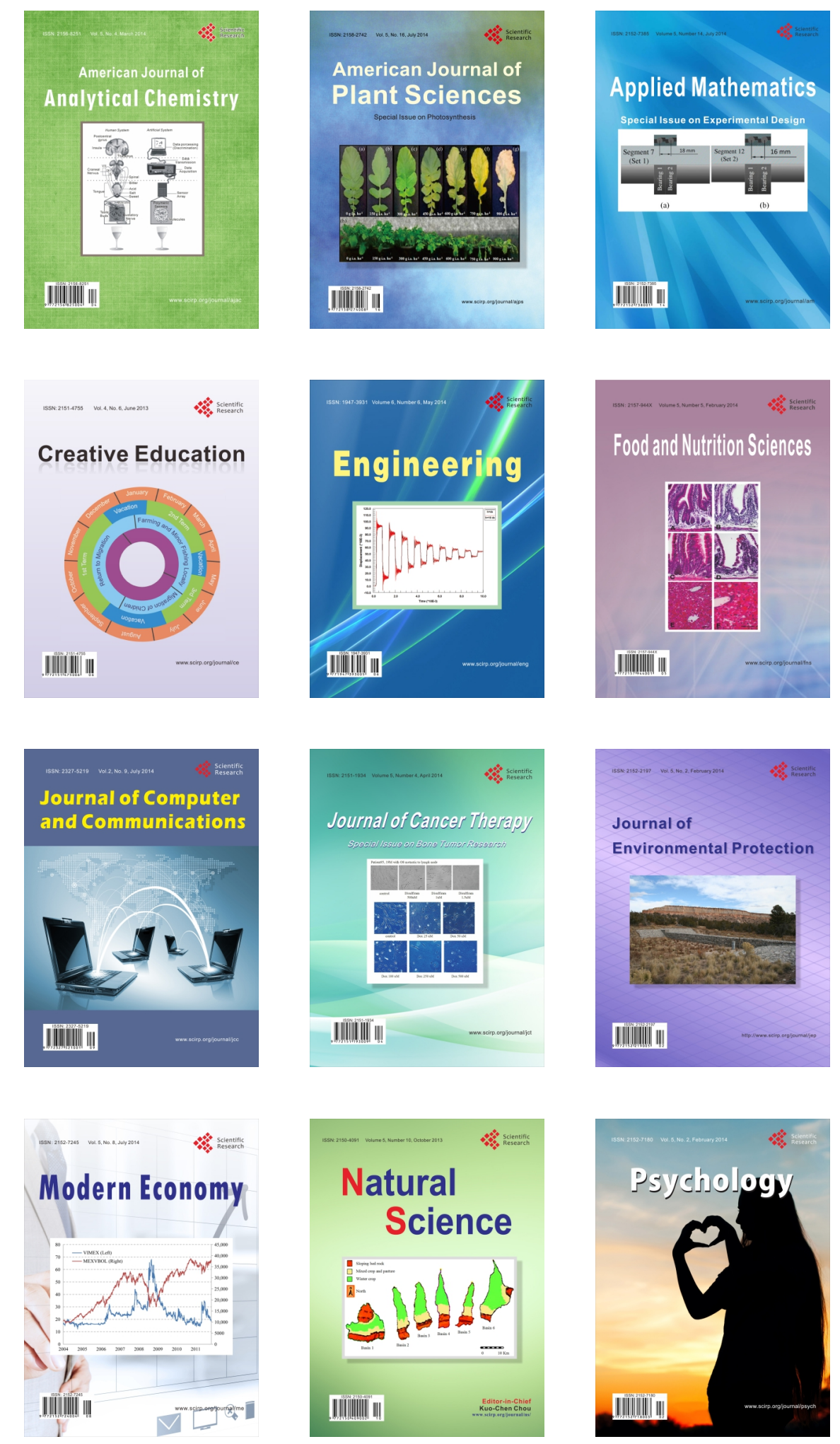